Western University

Scholarship@Western

Aboriginal Policy Research Consortium International (APRCi)

5-18-2009

\title{
Aboriginal affairs: Monologue or dialogue?
}

Vanessa Castejon

Université Paris III

Follow this and additional works at: https://ir.lib.uwo.ca/aprci

Part of the Comparative Politics Commons, and the Politics and Social Change Commons

Citation of this paper:

Castejon, Vanessa, "Aboriginal affairs: Monologue or dialogue?" (2009). Aboriginal Policy Research Consortium International (APRCi). 436.

https://ir.lib.uwo.ca/aprci/436 
This article was downloaded by: [University of Western Ontario]

On: 09 December 2012, At: 07:10

Publisher: Routledge

Informa Ltd Registered in England and Wales Registered Number: 1072954 Registered office: Mortimer House, 37-41 Mortimer Street, London W1T 3JH, UK

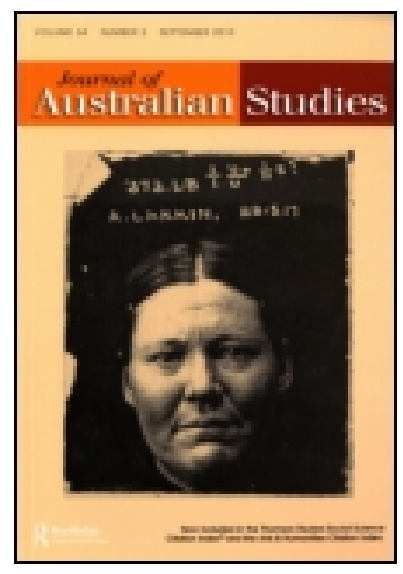

\title{
Journal of Australian Studies
}

Publication details, including instructions for authors and subscription information:

http://www.tandfonline.com/loi/rjau20

\author{
Aboriginal affairs: Monologue or dialogue? \\ Vanessa Castejon ${ }^{\text {a }}$ \\ a Teaching British politics since, Université Paris III \\ Version of record first published: 18 May 2009.
}

To cite this article: Vanessa Castejon (2002): Aboriginal affairs: Monologue or dialogue?, Journal of Australian Studies, 26:75, 27-31

To link to this article: http://dx.doi.org/10.1080/14443050209387800

\section{PLEASE SCROLL DOWN FOR ARTICLE}

Full terms and conditions of use: http://www.tandfonline.com/page/terms-and-conditions

This article may be used for research, teaching, and private study purposes. Any substantial or systematic reproduction, redistribution, reselling, loan, sub-licensing, systematic supply, or distribution in any form to anyone is expressly forbidden.

The publisher does not give any warranty express or implied or make any representation that the contents will be complete or accurate or up to date. The accuracy of any instructions, formulae, and drug doses should be independently verified with primary sources. The publisher shall not be liable for any loss, actions, claims, proceedings, demand, or costs or damages whatsoever or howsoever caused arising directly or indirectly in connection with or arising out of the use of this material. 


\section{Aboriginal Affairs: Monologue or Dialogue?}

\section{Vanessa Castejon}

On January 262002 , the thirtieth anniversary of the creation of the first Aboriginal tent embassy was celebrated. In 1972 the tent embassy emerged from the Black Power movement as a manifestation of the call for recognition of Aboriginal sovereignty and the right to self-determination. These claims have been raised continually by some prominent Aboriginal activists, but the main answer given by the government has been the creation of Aboriginal policies and sections for Aboriginal people within the Australian political system. The government, by different means, has brought Aboriginal activists within the system and has diverted attention from their aspirations. What I would like to point out in this article is that the government has answered claims for a dialogue with an imposed monologue. I would also like to stress that some activists have found ways to take advantage of the circumstances imposed upon them and have developed a dialogue from within governmental institutions. I do not pretend to give a full description of the different means used by Aboriginal people to gain recognition of their rights; I aim only to give an account of some strategies utilised by Indigenous Australians in their fight against political marginalisation.

In 1972, the first response of the government to Aboriginal political claims was radical: the police simply expelled the Aboriginal embassy from the lawn of what is now old Parliament House. This action generated much publicity for the Aboriginal cause. The following answers to Indigenous political claims were more moderate and, above all, less visible. In 1973, the Whitlam government used some of the rhetoric of the embassy protests when introducing what was called the selfdetermination policy. Prime minister Whitlam declared: 'The basic object of my Government's policy is to restore to the Aboriginal people of Australia their power of self-determination in economic, social and political affairs'. ${ }^{1}$ The selfdetermination policy was in fact self-management; far from what was asked for by Aboriginal activists, as it meant only greater participation in Aboriginal policy as defined by the government and not what is meant by the international definition of self-determination, which is the right to exercise a free political choice.

\section{The first 'Aboriginal' governmental institutions}

Not only did the government determine Aboriginal policy, it also answered claims for political independence by offering a determinate place to Aboriginal people within the Australian political system. In 1973 the Department of Aboriginal Affairs, composed of non-Aboriginal people, was created to administrate the money allocated to the governance of Indigenous Australians. Another organisation was born the same year, created by Gordon Bryant, then minister for Aboriginal Affairs. It was the National Aboriginal Consultative Committee (NACC). The NACC was elected by Aboriginal people and was supposed to assist the Department of Aboriginal Affairs. Unfotunately, the Department considered the NACC as a rival. After a report on the organisation in $1976,{ }^{2}$ it was dismantled 
and replaced by the National Aboriginal Conference (NAC). No negotiation was proposed to the place offered to Aboriginal people within the political system. If we consider Michael Dodson's declaration that 'Self-determination is to peoples what freedom is to individuals ... the very basis of their existence', then the negation of this right, manifest in the inclusion of Aboriginal activists within the system, can be considered as reclusion. The government answered claims to autonomy by political integration.

In the 1970 s and 1980 s, some Aboriginal people entered the political system, firstly the NACC and later the NAC, to attempt to change things from within. They tried to negotiate a compromise between the agenda of the government and that of Aboriginal bodies. An agreement, also called Makarratta, was asked for. In 1984, when the NAC became more virulent about the need for an agreement, it was simply dismantled with internal dysfunction offered as a rationale. ${ }^{3}$ No Aboriginal governmental institution was established to replace the NAC during the 1980s. At that time, with the coming of the celebrations of the bicentenary of federation, variously regarded as the discovery of Australia or the beginning of invasion, protests and claims became stronger. Promises were made by the government to appease the activists before the celebrations: Prime minister Bob Hawke promised a treaty but was defeated by his government. He had to recant his words and instead promise an 'agreement'. The difference between a treaty and an agreement is that an agreement can be made between two groups in the same country while a treaty was said to imply a possible recognition of sovereignty, as it is supposed to be made on an equal footing.

\section{The present institutions}

At the beginning of the 1990s, the government created two new 'Aboriginal' agencies, partly as a response to Aboriginal claims: the Australian and Torres Strait Islander Commission (ATSIC) and the Council for Aboriginal Reconciliation (CAR). ATSIC was the first to be created, in 1990, and was supposed to be a truly representative Aboriginal body in the Australian political system. ATSIC is said to be an independent body and is even considered as a nongovernmental organisation by the United Nations. Yet there seems to be suspicion surrounding ATSIC's image of independence, mainly because the organisation is resourced and controlled by the government. For example, in the early days of the institution, when the minister for Aboriginal affairs, Robert Tickner, said 'I have no power anymore, it's now ATSIC's responsibility', Aboriginal activist Gary Foley said that it was like a ventriloquist saying that the puppet was controlling the show. ${ }^{4}$ Among non-Aboriginal people also ATSIC is said to be too closely aligned with the government. During the ATSIC pre-election period in 2002, shadow minister for Aboriginal affairs Carmen Lawrence said that ATSIC president Geoff Clark was 'a little close to government' and she added 'that's what worries me about ATSIC at the moment'. 5 Geoff Clark answered: 'What do people expect - Geoff Clark the bomb thrower?' Geoff Clark has tried to negotiate with the government on Indigenous issues, following the government's policy of 'practical reconciliation'. At the same time, he has pushed ATSIC's political agenda since his election in 1999. Geoff Clark describes himself as a 'progressive thinker', but is still the vice-president of the Aboriginal Provisional Government, 
which is radical in its declarations. Geoff Clark has been described as a disguised moderate by some Aboriginal activists, like Robbie Thorpe, who said he was a Trojan Horse. ${ }^{6}$

Today ATSIC is not disregarded as a political force, as it was in its nascency. At that time, some Aboriginal people considered it to be treacherous: Robbie Thorpe compared it to the Native Police and Murrandoo Yanner called ATSIC commissioners 'Jacky-Jacky', also referring to 'the Aborigines who sided with the police, while their people were being massacred or moved'. ${ }^{7}$ Kevin Gilbert, who strongly advocated the recognition of Aboriginal sovereignty, even compared ATSIC to an Aboriginal reserve in government. Aboriginal spokesperson Patrick Dodson, the first chairperson of the Council for Aboriginal Reconciliation, in his Wentworth Lecture in 2000, expressed the same feeling:

The reality was that we became slaves of a series of government programs and policies that continued to determine our political and social lives; a sort of 'assimilation with consultation'. The same bureaucracies that supplied the Native Protectors provided us with mandarins and field officers. ${ }^{8}$

Like the previous organisations, ATSIC is used by the government to confine political activists within a segregated part of the political system. Speaking about Aboriginal activists in governmental institutions, an Australian journalist mentioned American president Lyndon Johnson, who said of one of his bureaucrats: 'I would sooner have him inside the tent spitting out, than outside the tent spitting in'? This could, indeed, apply to the confinement of Aboriginal activists within governmental institutions.

The Council for Aboriginal Reconciliation was created in 1991 in response to one of the 339 recommendations of the Commission on Aboriginal Death in Custody. CAR was, in a way, an answer to Aboriginal claims for a treaty, as it was supposed to establish a 'document' or 'documents' of reconciliation. CAR was in fact only a means to improve the relations between Aboriginal and non-Aboriginal people without having to define the place of each group within the Australian system. CAR was focused on building a common identity on the acknowledgment of the past conflict rather than acknowledging different identities to imagine common aspirations. After ten years of reconciliation, Geoff Clark said:

Reconciliation helped to clarify amongst ourselves what it was that we were after. It helped to clarify amongst the non-Aboriginal community the level of ignorance and the level of non-understanding. ${ }^{10}$

Reconciliation put an end to the Great Australian Silence, ${ }^{11}$ but no words were spoken for the future. The non-Aboriginal population was asked to believe that reconciliation was a priority for Aboriginal people when Aboriginal people involved in the fight for political rights seem to have considered it, above all, as a priority for non-Aboriginal people. Geoff Clark spoke about Reconciliation as a 'Whitefella's business'12 and Gary Foley mentioned a 'non-indigenous concept' 13 Some said that it was too early to get these two groups together. Aboriginal radical activist Isabell Coe said: 'They speak about Reconciliation, when they should speak about ending the war' ${ }^{14}$ Some, indeed, asked for conciliation before reconciliation. A conciliation, or a 'peace process' in the words of Isabell Coe, could have been a treaty. 
Reconciliation was in fact a social answer to a political claim. It was only used during the ten-year lifespan of the Council for Aboriginal Reconciliation as a channel for Aboriginal claims. For Les Malezer, international representative for the Foundation for Aboriginal and Islander Research Action (FAIRA), ${ }^{15}$ reconciliation is something Indigenous people did not ask for. One of his recent essays is entitled 'Reconciliation? Sounds ok but "no", thanks!' This essay ends up with those words: 'Forget about Reconciliation, I never asked for it. I want a treaty'. ${ }^{16}$ For Geoff Clark also, 'Reconciliation was a distraction from the treaty debate and we wasted ten years'. ${ }^{17}$ According to Kevin Gilbert, the position in which the government has placed Aboriginal people through reconciliation is one of victim, ${ }^{18}$ not of a sovereign people, and he rejects it. Patrick Dodson, in another context said, 'we are still chained to our thinking and continue to seek the station manager's nod of approval'. ${ }^{19}$ For many Aboriginal activists, reconciliation seems to be evidence of the government's disregard of Aboriginal voices, or that it is carefully selecting the ones listened to.

Reconciliation has been built upon a myth of peace. Aboriginal governmental institutions, and many other non-Aboriginal decisions on Indigenous issues, are supposed to have been the pillars of the peace process and reconciliation is presented as their natural successor. Reconciliation even celebrates this 'peace'. For example, the beginning of Reconciliation Week is on May 27, the anniversary of the 1967 referendum, and its last day is on June 3, the day of the Mabo decision. The referendum participated in the myth created by the government to pretend that it was working for Aboriginal people. The myth has taken such proportions that many Australians think that the referendum gave Aboriginal people Australian citizenship the right to vote. ${ }^{20}$ For example, Kim Beazley, the former leader of the Labor Party in 2000 said that 'It led to true citizenship and voting rights for many of our Indigenous people'. ${ }^{21}$ In fact, the referendum only allowed Aboriginal people to be counted in the census and to be under the legislation of the federal government. The government calls the referendum (or the myth born from the referendum) the first step to reconciliation. ${ }^{22}$ For Gary Foley, 'many Kooris ${ }^{23}$ today feel that we should not get too excited about reconciliation as it is a concept that will deliver as little in terms of land and economic justice to Aboriginal peoples as what the Referendum did'. ${ }^{24}$ The myth has been used to pretend that peace between Indigenous and non-Indigenous people was already a fact; that Australia was a 'lucky country' which could offer 'a fair go for all'. The myth was used to pretend that it was the beginning of a series of governmental measures to 'help' Aboriginal people. These measures included the creation of the Aboriginal governmental institutions.

The institutions created by the government to show that Aboriginal people were taking part in the decision making process were imposed on Aboriginal people and what was supposed to be a means of creating political dialogue turned out to be an imposed monologue. Since the beginning of the 1990s, Aboriginal activists have found various means to redirect the debate towards their own aspirations. Some entered the government-created institutions and managed to influence them in support of Aboriginal political rights. For example, ATSIC is now supporting a treaty under the influence of chairman Geoff Clark, who is the first ATSIC president to be elected. ATSIC has established a National Treaty 
Support Group and a National 'think tank' to work on the treaty issue. It is also organising consultations of Aboriginal people on that topic. Geoff Clark has also, with the support of a few other members of the Council for Aboriginal Reconciliation, managed to get the Council to include the treaty issue in its final recommendations in December 2000. I would like to underline that reconciliation was proposed as an answer to treaty claims at the end of the $1980 \mathrm{~s}$, and that the conclusion of CAR's ten years of work on reconciliation was that a treaty was needed. The government used the Council to redirect Aboriginal claims, but when claims for a treaty began to resurface, this time inside the institution, the government expressed its disapproval. The government seems to have killed the policy it put in place because it saw it slipping from its hands. On August 292002 , after a motion introduced by the only Aboriginal senator, Aden Ridgeway, an inquiry was launched to investigate the governments progress towards reconciliation. In a paper given last year at the European Association for Studies on Australia (EASA) conference in Lecce, Italy, I argued that the means used by the Australian government against Aboriginal political aspirations was close to political apartheid. I would say that the government's tendency to manage Indigenous issues solely within Aboriginal Affairs is, again, close to political apartheid. 